\title{
The role of epistemic communities and expert knowledge in the European Neighbourhood Policy
}

\section{Abstract}

This article fills a gap in the literature on the European Neighbourhood Policy (ENP) by examining the role that epistemic communities play in the policy. It follows an interdisciplinary approach for categorising their role in the ENP and the use of their knowledge by policymakers. Based on the examination of two key areas of the ENP, anti-corruption and rural development, the study challenges one-dimensional assumptions, which claim that expertise and knowledge improve the technicaleconomic efficiency of EU policies. The findings of this research suggest that the knowledge of epistemic communities takes three different forms for policymakers: political/symbolic, instrumental and conceptual.

Keywords: Epistemic communities; knowledge utility; ENP; anti-corruption; rural development

\section{Introduction}

The last two decades have witnessed a steady increase in the European Union's (EU) efforts to shape its neighbourhood's setting. A key milestone in this effort is the launch of the European Neighbourhood Policy (ENP) in 2004, which aimed to strengthen the security, prosperity and stability of the region. A few years after its creation, the EU proceeded to a wide consultation and revised the ENP in 2011 and in 2015.

Following the Arab revolts and the challenges in the Eastern borders of the EU, research in the area has mainly focused on comparisons between the revised policy and the work of the ENP before 2011 or on (suboptimal) outcomes, either of the decision-making process or of the implementation of the policy (Börzel \& Hüllen, 2014; Roccu \& Voltolini, 2018; Teti, 2012). So far, little emphasis is paid in the role of expertise and knowledge in the construction of the ENP. The main aims of the article are to explain the role of experts and the different functions of knowledge in the policy.

As expertise is shared by different actors in the EU decision-making, a challenge for this study is to identify the expert groups that influence policy outcomes of the ENP. The article utilises the concept of 'epistemic communities' for explaining the role of expert groups in the ENP. An epistemic community is 'a network of professionals with recognised expertise and competence in a particular domain and an authoritative claim to policy-relevant knowledge within that domain or issue area' (Haas 1992).

The specific characteristics of epistemic communities are explained in detail in the next section, but at this point it should be mentioned that although the ENP literature has identified the importance of NGOs (Voltolini, 2016) and communities of practice (Bicchi \& Bremberg, 2016) in providing expertise for improving the EU rules beyond EU borders, advocacy coalitions and communities of practice are not adequate for this study for the following reasons. An advocacy coalition is motivated by values rather than by professional norms (Keck \& Sikkink, 1999) while practice has a broader meaning, as the term indicates 'an organised constellation of different people's activities' (Schatzki, 2012, p. 13). In this sense, communities of practice may share a common enterprise (as do epistemic communities), but the definition does not carry the normative load of epistemic communities, as communities of practice do not necessarily share the same causal beliefs and norms.

In order to achieve the aforementioned aims the article draws lessons from typologies that explain functions of knowledge (Boswell, 2008; Dunlop \& Radaelli, 2013; Weiss et al., 2005) and it addresses the following questions: What is the role of epistemic communities in the ENP? Does 
knowledge have a single function for decision-makers and which are the factors that determine its utility?

Besides shedding some light on the role of epistemic communities in the ENP, the article contributes to the literature of the ENP, as it systematises the ways that policymakers use expertise. Although the literature on knowledge utility has acknowledged that the role of experts and the use of knowledge varies and is contingent (Dunlop \& Radaelli, 2013; Radaelli, 1999; Van Ballaert, 2015; Zito, 2001a, 2001b), the domain of EU foreign policy is treated as unique terrain of expert knowledge. Here, two issues deserve attention. First, among the few studies that explain the role of epistemic communities in EU foreign policy (which mainly focus on the European Security and Defence Policy (Cross, 2011; Faleg, 2012; Howorth, 2004)); there is an implicit consensus, that when experts are called on, they manage to shape decision-making. As a result, the dominant perception is that expert knowledge has a single and substantial function for policymakers.

This study challenges these conclusions. It claims that in order to make better sense of policy outcomes the role of epistemic communities and function(s) of policy knowledge need further elaboration. More specifically, the findings of this research suggest that the knowledge of these networks of experts takes three different forms for policymakers: political/symbolic, instrumental and conceptual. In addition, the article argues that epistemic communities (and their knowledge) can play a bimodal role in ENP decision-making. This is a result of the timing of when they enter the decisionmaking process, the existence (or not) of established patterns and other actors and the uncertainty over relevant policy challenges.

The article focuses on two key areas of the ENP: anti-corruption measures in the Eastern partners and rural development in the south rim of the ENP. The case studies are selected for two reasons. First, due to the problems that the ENP countries faced in the last decade, the two sectors are characterised by epistemic uncertainty. Uncertainty is defined differently by theories of international relations (Rathbun, 2007), but analysts of the ENP have argued that epistemic uncertainty stems from the absence of distinct templates (in the area of anti-corruption) and misinterpretation of available information, which led to wrong decisions (in the area of rural development) (Narro \& Moreno, 2014). This situation forced policymakers to rethink their existing approach and offered a window of opportunity for experts to participate in the decision-making process. In addition, the different origins of epistemic uncertainty help us to see how expert knowledge is utilised under different conditions in the ENP.

Second, these two areas are important in the ENP. Since the beginning of the policy, the fight against corruption has been declared as a priority area for action under the EU's Good Governance Agenda (Wichmann, 2010), while rural development has increased its prominence in the ENP agenda after the revision of the policy in 2011, when it was highlighted as a key for the promotion of sustainable growth in the neighbouring countries (IEMed, 2016).

As there is not any systematic research about epistemic communities in the ENP, the article methodologically is based on qualitative analysis of official documents produced by the EU and other stakeholders. These are corroborated and triangulated with secondary sources and interviews with members of epistemic communities in order to evaluate their work.

The article starts by discussing the role of epistemic communities in the EU and categorising the use of their knowledge. It then proceeds to analysis of the two case studies. The conclusion summarises the findings of this work.

\section{Epistemic communities and the use of expert knowledge in the ENP}

The term 'epistemic communities' was introduced in the field of international relations by Haas (Haas, $1989,1992)$. According to Haas an epistemic community is 
a network of professionals from a variety of disciplines and backgrounds. They have (1) a shared set of normative and principled beliefs [...]; (2) shared causal beliefs, which are derived from their analysis of practices [...]; (3) shared notions of validity - that is, intersubjective, internally defined criteria for weighing and validating knowledge [...]; and (4) a common policy enterprise - that is, a set of common practices associated with a set of problems to which their professional competence is directed. (Haas, 1992, p. 3)

Research that explores the role of epistemic communities in EU internal policies has identified several political and economic variables (such as power dynamics and antipathies between stakeholders, economic disparities and politicisation of issues) that determine their input in the decision-making process (Gornitzka \& Holst, 2015; Howorth, 2004; Verdun, 1999). Yet, despite these restrictions, in most cases the conclusion is that their impact is significant. Ideas from science and technology are assumed to influence decisions (usually due to their internal merits and to the help of the European Commission, which forges transnational alliances) (Faleg, 2012; Van Ballaert, 2015).

Even if decision-makers need the input of experts, studies in policy learning show that the way that authorities use knowledge varies and it is contingent (Boswell, 2008). Research in the broader field of policy learning can be helpful for categorising the interaction of epistemic communities and authorities and the use of the end product that the former produce (knowledge). At this point it is important to mention that knowledge is different from information. Information is data relevant to the knower, whereas knowledge is the interpretation of information "by the knower in the form of "cause and effect" and "means and ends" propositions as well as "right and wrong"' (Bicchi, 2014, p. 241).

The academic scholarship has used a variety of methods in order to link knowledge utilisation to political processes. Often the literature draws lessons from the mechanisms that Adler and Haas identified in 1992. These are policy innovation, policy diffusion, policy selection, policy persistence and policy evolution (Adler \& Haas, 1992). Although useful for showing how policies progress over time (Faleg, 2012), these mechanisms are not adequate tools for this article, as they do not explain what type of knowledge shows up in policy outcomes and how is used by policymakers. In fact, even until today, several experts argue that the literature on the use of knowledge grows independently from studies on policy process, policy implementation and evaluation (Daviter, 2015; Jones et al., 2014).

Besides a very limited number of studies which, as mentioned in the introduction, explain the role of NGOs or communities of practice for the provision of expertise (Bicchi \& Bremberg 2016; Voltolini 2016), in the ENP literature expert knowledge and knowledge utilisation have been either addressed indirectly or as a secondary part of questions which focus on different aspects of the policy. In most cases, these questions are about (limited) rule transfer or discourse building. For the former question, early studies on the ENP took the production of knowledge for granted and treated it as practices that stemmed from the enlargement process. Within this framework, the limited application of the EU's knowledge had to do with the absence of incentives for the partner countries (Kelley, 2006; Lippert, 2006). Later studies added other contextual factors (such as the compatibility of domestic agendas with EU knowledge) that shaped the usefulness of EU expertise for the development of the neighbourhood (Casier, 2011; Delcour, 2016). Despite the different explanatory variables, both early and later works mostly placed their emphasis on problematic knowledge management (by the ENP countries).

Regarding discourse building, the literature very rarely separates the production and use of knowledge from norms and values. When this black box of mixed ideas is unpacked, analysts often see discourse as a product of power dynamics between institutional actors (the EU institutions, EU 
member states and neighbours). Most studies tend to investigate the role of these actors for (re)framing problems and 'giving meaning to things' in order to legitimise intervention (Ademmer, 2015; Jones \& Clark, 2008). Analyses that draw lessons from critical theories suggest that knowledge is used for establishing the interventionary role of the ENP, as the policy seeks to (re)define the discourse (in a range of issues such as borders and identities) in order to allow the EU to attain dominance in the region. Other studies highlight different restrictions of discourse building, such as confusion, problematic coordination and conflicting positions, which indirectly result in the suboptimal use of knowledge.

For explaining how knowledge is used by policymakers and how it affects policy choices, the article is based on the work of Weiss (1977), Weiss et al. (2005), Dunlop (2014) and Daviter (2015). Here it must be mentioned that the following classification does not attempt to produce a comprehensive typology bridging the gap between knowledge utility and (EU) public policy studies. Its aim is to enrich our understanding of the role that expert knowledge plays in different aspects of the ENP. The following paragraphs classify knowledge as political/symbolic, instrumental and conceptual.

Political/symbolic knowledge suggests that policymakers use knowledge to inform decisionmaking or for terminating programmes. Dunlop argues that 'actors scan the epistemic landscape for evidence useful to their cause - ensuring an audience, at least initially, for a wide range of views' (Dunlop, 2014, p. 219). In this case, the EU institutions engineer the support of experts, whose input is used as a vehicle for public relations.

Several examples show that the EU has used expert knowledge for advancing an agenda of which the aims are already decided by policymakers. For the EU's Common Fisheries Policy policymakers used outdated maximum yields, in order to support as evidence-based their preferences for fishery management (Mesnil, 2012). For the ban on hormones in meat, the EU used epistemic communities in order to downstream policy (Dunlop, 2010), while the EU's Renewable Energy Directive in 2009 was accused of being, rather than an evidence-based policy, a process of 'policybased evidence gathering' in order to promote the use of biofuels (Sharman \& Holmes, 2010).

Instrumental knowledge gives direction to policy (Weiss et al., 2005). Especially in times of uncertainty, decision-makers turn to epistemic communities in order to make better sense of complex phenomena. In this case what is observed is a two-way flow of information. Policymakers inform epistemic communities about the aims of their agenda, while the latter provide technical knowledge about related matters. As a result, experts play the role of the legitimate and accepted teacher.

Verdun (1999) brings a useful example of this process, where an epistemic community acted as a consultant who offered valuable recommendations in the highly politicised issue of creation of the Economic and Monetary Union (EMU). Its knowledge did not generate a new initiative, as the Single European Act (SEA) had a clause that 'would necessitate the creation of EMU' (Verdun, 1999, p. 311). The epistemic community for the EMU was formed after the SEA, for analysing the technical challenges the project would face (such as inflation, interest rates). Its expertise improved the suggested plan and facilitated the cooperation between the European Commission and the member states.

At the highest level knowledge becomes conceptual. Conceptual knowledge differs from instrumental knowledge in the sense that it is used for the redefinition of common problems, whereas instrumental knowledge is used for identifying potential problems or shortcomings in the EU's policies/initiatives and leads to improvements.

It should be noted that redefinition of problems does not necessarily indicate paradigmatic shifts in the implementation of EU foreign policy, nor does it suggest any sort of contest with structures of political authority. In fact, when the European Commission is seen as an epistemologically closed system, then it is logical to assume that it very rarely adopts unconditionally 
the position of opposing bearers of knowledge. As Dery argues, as the evaluation of new knowledge is filtered by bureaucracies through pre-existing lenses and frames of knowing, new information that conflicts with the organisational premises is typically supressed or rejected (Dery, 1986, 1990). In this case conceptual knowledge is incremental and compatible with the existing policy structures (knowledge creep). On rare occasions when established patterns are challenged and fundamental alterations occur then conceptual knowledge takes the form of knowledge shift (Daviter, 2015).

An important ramification: knowledge is not used in just one way in a given policy area. As political issues have different aspects, the use of expert knowledge can be in some areas political/symbolic and in others instrumental or conceptual. As stated above, uncertainty that arises from crises, the relationship between experts and policymakers, politicisation of issues and alignment between the goals of epistemic communities and these of policymakers are factors that shape the way expert knowledge is used in policymaking (Cross, 2013).

The following cases illustrate these variations in different areas of the ENP. As stated in the introduction, these are related to the fight against corruption in the Eastern borders of the EU, and to the EU rural development initiative towards the Southern partners.

\section{The Eastern Partnership Panel on fighting corruption: Political/symbolic use of knowledge}

The Eastern Partnership (EaP) was created in May 2009 as a step towards more differentiation between the Southern and the Eastern members of the ENP. For accelerating political reforms in the partner countries the EaP introduced four thematic platforms: democracy, good governance and stability; economic integration and convergence; energy security; and contacts between people.

This categorisation offered the opportunity to a wide range of actors to participate in the policy through the creation of expert panels. Six expert panels were formed in different areas of the first thematic platform (democracy, good governance and stability). These were public administration reform; integrated border management; migration and asylum; improved justice; security cooperation; and fight against corruption.

Since the beginning of the EaP, the fight against corruption was very high on the agenda (Council of Europe, 2018a). Despite its prominence, however, the EU lacked specific tools to fight corruption. The Action Plans (APs) included generic guidelines without any benchmarks for measuring progress and with very few provisions for anti-corruption measures. In addition to these weaknesses, the lack of responsible agencies created an even more problematic setting for fighting corruption. For some scholars, this type of uncertainty and lack of institutions were responsible for the pathologies of Europeanisation in the region (Börzel \& Pamuk, 2012).

The expert panel was formed in order to reduce uncertainty by assisting policymakers in the design of effective corruption prevention measures. The expert panel is an epistemic community, as it brings together a network of professionals from different disciplines, who share the same set of beliefs and notions of validity. The experts come from the Council of Europe (CoE), corruption prevention agencies, academia and international anti-corruption NGOs (Personal interview 09/04/2019; Personal interview 24/10/2019; Personal interview 01/11/2019). The panel was formed in autumn 2010 and its work plan was approved in May 2011.

In accordance to Haas's four criteria, the elements that make this expert group an epistemic community are the following. Regarding the first two criteria, this group shares the same normative and causal beliefs about corruption (Personal interview 09/04/2019; Personal interview 24/10/2019; Personal interview 01/11/2019). These beliefs are based on a liberal technocratic discourse. Its main assumptions are that corruption is a universal problem and primarily a managerial challenge that can be addressed without becoming political (Di Puppo, 2010). Although corruption is universal, the 
general tone is that the causes of corruption are endogenous and can be found in the interactions between civil servants and the public.

In addition, this group shares the same notions of validity regarding the existence and magnitude of corruption. Its primary belief is that corruption can be quantified. Drawing examples from New Institutional Economics, the methodology for the quantification of corruption goes beyond typical econometric analyses about its impact on growth and includes more refined objective and composite indicators (Council of Europe, 2018a). Yet, even if the diagnostic reports are more refined and include the study of institutions for linking corruption to development, the underlying analytical framework is that rational self-interested agents respond to initiatives in their environment (Bukovansky, 2006). According to this approach, the underlying reasons for corruption can be isolated and documented.

Finally, the group has a common policy enterprise (Personal interview 09/04/2019; Personal interview 24/10/2019; Personal interview 01/11/2019). The focus of anti-corruption strategies should primarily be on administrative changes of the worst-performing sectors of the public service of the ENP states. There is also a consensus among the members of this epistemic community that corruption is a concern that requires a multilateral approach. As the ENP partners lack resources, EU funding for anti-corruption strategies and monitoring by civil society organisations (CSOs) are essential components for making the governments of the neighbouring countries more accountable (Di Puppo, 2010).

This approach differs from the bottom-up logic of other sectoral actors (especially local NGOs). Key assumptions of this logic are that the fight against corruption must be contextualised according to the particularities of each country and that corruption is not only a managerial issue, but primarily a political one (Di Puppo, 2010). From this perspective, there is little recognition by international anticorruption agencies of the interactions between the local and the global, and of the strategic interests that inform corrupted practices.

The supporters of this view attack also the methodology of the liberal technocratic discourse that this epistemic community follows. They argue that the quantification of corruption and the focus on the moral integrity of public servants are not enough to tackle the diffused nature of the problem (Bukovansky, 2006). The provision of incentives for changing the structure of public services cannot act as a replacement for the lack of attention on political agency. The most important elements of an anti-corruption strategy are public participation and the strengthening of democratic institutions.

Although policymakers tend to link the two discourses, using as glue the need for deeper democracy and a rupture with the Soviet past, the two approaches suggest a different working method. On one hand, besides the adoption of Western-style standards, the liberal technocratic approach supports the transition towards a market-based economy and a smaller state as a corrective to corruption. At the same time, this approach allows the reinforcement of a strong (and determined) executive to lead the battle against corruption. On the other hand, the bottom-up approach focuses on the opening of the public sphere to more voices and the decision-making to independent control bodies (such as the judiciary and regulatory bodies).

The EU and key actors of this epistemic community (such as the COE) have supported the former working method, even before the creation of the expert panel. Actually, the origins of this epistemic community can be traced in the efforts of the EU to stabilise the new Balkan states after the partition of Yugoslavia. Although the priorities were different (security in the Balkans, democracy promotion in the EaP), the main participants of this expert group were key actors in the construction of the Stability Pacts in the former region and drew lessons from them in order to enhance cooperation among the EaP countries (Personal interview 09/04/2019). Since the end of the 1990s the European Bank for Reconstruction and Development and the CoE's Groups of States against Corruption (GRECO) generated anti-corruption programmes with a standardised list of measures, which served as a road 
map for the national strategies of the post-communist transition countries (Tisne \& Smilov, 2004). The main asset of these programmes is that the anti-corruption objectives are vague, so 'they can be integrated into many political agendas or private projects' (Sampson, 2008, p. 4).

Success stories of anti-corruption initiatives were based on the responsiveness of the governments of the ENP countries to these programmes. For example, in Georgia Saakashvili's government adopted GRECO's recommendations in 2005 and the national plans for corruption prevention focused on changes in the public sector and promotion of neoliberal reforms (Di Puppo, 2014). Despite the fact that Saakashvili further centralised decision-making for consolidating his power (Kupatadze, 2012), the country was considered as a top reformer in several anti-corruption and business reports (Schueth, 2011). For some scholars, it was exactly this greater centralisation of political power that allowed the Georgian government to perform better than other EaP states (Nasuti, 2016).

As stated in the previous section, the timing of entering the policy process and the alignment of goals between key stakeholders and epistemic communities are factors that shape the use of expert knowledge by policymakers. In this case, the foundations for the anti-corruption strategies had been set more than a decade before the creation of the EaP, and this epistemic community has the same liberal technocratic view of corruption as GRECO.

As a result, the expert panel seems to mitigate cognitive uncertainty, but its actual impact on the discourse about corruption is minimal, as it mainly elaborates components of older frameworks. The Memorandum of Understanding between the EU and the CoE in 2007 confirmed the role of the latter institution in the EaP countries and established the framework that GRECO had developed as the main toolbox for fighting corruption ("Memorandum of Understanding between the Council of Europe and the European Union," 2007). The new knowledge that the panel has produced fits into this toolbox, as it is mainly about the publication of detailed reports and recommendations for strengthening prevention and fighting corruption (Council of Europe, 2017, 2018c). In fact, through the EaP, the EU continues to support GRECO's work in the region and the expert panel is used as a vehicle for this task.

More specifically, funded by the ENPI, the CoE organised in 2010 bridge activities in order to link GRECO's framework to the aims of the newly formed EaP in order to support the operation of the Panel on Fighting Corruption. Key actors in the implementation of these activities were the Directorate of Human Rights and Legal Affairs and the Directorate of Cooperation (Economic Crime Division) of the CoE. During the operation of the bridge activities anti-corruption experts from the CoE with knowledge of the EaP countries were 'secured in order to carry out the preliminary reviews and analysis which in the end will serve as the basis and facilitate the regional peer-reviews, discussions, and recommendations' (Council of Europe, 2010, p. 3).

The outcome of the bridge activities is that the work programme of the EaP in this area (20142017) follows the recommendations of GRECO for implementation of the bilateral objectives of the APs that the ENP partners signed with the EU (European Commission, 2014). Actually, the progress reports of the CoE cover the basic actions and the benchmark progress of the ENP partners (Council of Europe, 2018b).

Besides the production of detailed analyses for anti-corruption activities in the ENP countries, in this division of labour, the work of the expert panel is reduced to reproducing and circulating the international standards and organising workshops for facilitating discussion between stakeholders. These discussions mainly contextualise the aforementioned standards (Personal interview 24/10/2019). As a result, the knowledge of this epistemic community is used for political and symbolic purposes. In line with critical studies on corruption, a key lesson from this case study is that the EU advances an agenda, which treats corruption as a phenomenon related primarily to economic advantage and rent seeking. Towards this direction, the knowledge of the expert panel is used for 
legitimising purposes, as it offers the EU the epistemic authority to direct resources to actions consistent with the liberal technocratic approach against corruption. The relevant technical reports underline as root causes of corruption the long bureaucracy and the ethics in the public service of the ENP countries (Council of Europe, 2018c). As a result, the links between different state forms that inform corruption (as a means for (re)production of power) are overlooked.

However, the existing evidence does not necessarily suggest that this situation occurs due to the efforts of the EU for prominence in the neighbourhood. The existence of the expert panel allows the EU to be seen as a facilitator of corruption prevention measures and as an actor that is open to the wider civil society, even if the strategy that it supports does not allow a lot of room for local CSOs.

\section{Epistemic communities and the EU's rural development policy in the ENP countries: A case of instrumental and conceptual knowledge}

The Arab revolts were an awakening for policymakers in the EU regarding the shortcomings of the ENP in the area of rural development up until 2011. The EU institutions acknowledged that even if previous initiatives assisted the Arab Mediterranean countries (AMCs) to increase their production, these strengthened the region's bigger farmers (Rinaldi, 2012). In addition, the APs vaguely addressed various threats in the Arab Mediterranean countryside (such as rural poverty, unemployment, social inclusion, food security and decentralisation of the decision-making process). In line with the review of the ENP in 2011, which underlined the need for inclusive growth and support to small and medium enterprises (SMEs), the EU needed a new working method that could improve lives in rural areas (Rinaldi, 2012) and 'an agricultural sector geared to small farmers' (Narro \& Moreno, 2014, p. 18).

In order to prove its commitment to the principles of the reviewed ENP, the European Commission decided to draw lessons from rural development programmes that were implemented in the New Member States (NMS). This was materialised through the creation of the European Neighbourhood Programme for Agriculture and Rural Development (ENPARD) in 2012. According to the former Commissioner for Agriculture and Rural Development, Dacian Cioloş, the EU capitalised on effective working methods 'in particular during the accession of the NMS' (European Commission, 2012).

The uncertainty after the revolts in the AMCs and the knowledge that experts had gained during their work in pre-accession rural development programmes in the NMS allowed them to assume a central position in the coordination of ENPARD (Kourtelis, 2018). CIHEAM-IAMM in Montpellier, which comprises the International Centre for Advanced Mediterranean Agronomic Studies, was contracted by the European Commission to coordinate ENPARD and to foster the political dialogue between the EU and the ENP Southern partners regarding their rural development (CIHEAMIAMM, 2012b).

The ties that CIHEAM-IAMM had with rural institutes in the AMCs were crucial for the formation of an epistemic community, which shared the same normative and causal beliefs and the same orientation towards the future of rural development of the Arab Mediterranean countryside. Besides CIHEAM-IAMM, its members are agronomic research institutes of the ENP countries (CIHEAMIAMM, 2014).

Which elements prove the existence of this epistemic community? Its members share the same normative beliefs about rural development. Its cognitive framework is based on the idea of integrated rural development (Kourtelis, 2018; Personal interview 14/10/2014). The logic of integrated rural development is multisectoral and encourages the creation of synergies between local actors (such as local authorities, trade unions, the private sector and NGOs). The new approach builds on local knowledge in order to provide contextualised solutions to the problems of small farmers (Ray, 2000). 
The diagnostic reports of this epistemic community illustrate that its members share the same causal beliefs about the threats of rural development in the AMCs. The most important are the poor managerial skills of small farmers, environmental degradation, poor infrastructure and the absence of programmes for social cohesion in rural areas (CIHEAM-IAMM, 2012a).

The agronomists and agricultural economists of this network also share the same notions of validity for weighting knowledge in their domain (Personal interview 14/10/2014; Personal interview 15/10/2014). Besides the econometric methodology that is followed in most reports, the same notions of validity are also reflected in the operation of the programme. ENPARD asks the advisors who receive training from it to tie agricultural research and training workshops of small farmers to the ideas of competition, risk and productivity.

Finally, the members of this epistemic community share the same policy enterprise. This relies on the knowledge of CIHEAM-IAMM about rural development programmes in the EU and more specifically about the operation of the LEADER programmes (Personal interview 14/10/2014). Based on this experience, the epistemic community advocated the creation of Local Action Groups (LAGs), which generate partnerships between small farmers, businesses, the public and voluntary sectors. Consistent with the logic of integrated rural development and with the mandate of the revised ENP to help SMEs, LAGs allow small farmers to have a bigger say in the execution of rural development projects, as they coordinate the relevant business plans (Ray, 2000). LAGs serve also as a vehicle for the further democratisation of rural areas, as they amplify the voice of local actors. This logic is in line with the promise of the EU to support deep democracy in the AMCs, and differs from the logic that informed the previous work of the APs. Until 2011 the APs advocated sectoral policies, which were coordinated by (and reinforced) the central authorities of the ENP partners (European Court of Auditors, 2013). Before the Arab revolts, rural development was considered as an automatic result of the increase of food production.

The fact that CHEAM-IAMM had cooperated in the past with DG Agri for the LEADER programmes allowed this epistemic community to gain very early access to policymakers in the EU and to present its new approach for the development of the Arab Mediterranean countryside (Kourtelis, 2018). In addition, the organisation of workshops during the start-up phase of ENPARD (2012-2014) allowed this network to communicate its working method and to consolidate the support of a wide range of new, but relevant stakeholders in the AMCs. These include trade unions, rural NGOs, small farmers' syndicates and civil servants (CIHEAM-IAMM, 2014).

This new bottom-up approach has already brought some positive changes to the countries that joined the programme at its early stages (Morocco, Tunisia and Egypt). Through ENPARD and the introduction of a Joint EU Rural Development Programme, Egypt was convinced to include in its national plans measures for more efficient management of water and waste in rural areas. Joint meetings and workshops with public servants from Morocco and Tunisia added two new axes to the national plans of the two countries: training of small farmers and measures for sustainability of resources (EU Neighbourhood Info Centre, 2015).

Another innovative element of the new discourse for addressing rural poverty is the creation of agricultural cooperatives and advisory services for small farmers (CIHEAM-IAMM, n.d.-b). The introduction of such organisational structures marks a big difference from the previous APs. As stated above, the focus of the APs on increasing food production benefitted large producers. At the moment of writing ENPARD has already established agricultural services and awareness campaigns for small farmers in the pilot areas in Morocco and Tunisia (CIHEAM-IAMM, n.d.-a; EU Neighbourhood Info Centre, 2015).

These examples indicate that the criticism of the previous EU initiatives, which benefited established food producers in the AMCs, the high degree of uncertainty for dealing with threats in rural areas after 2011 and the access of this epistemic community to other stakeholders allowed new 
knowledge to be introduced in certain areas of ENPARD. Conceptual knowledge led to significant changes (knowledge shift). However, other areas of the programme are more rigid and as in the case of anti-corruption practices, they were introduced almost a decade before the revolts and are not easy to change. There, experts produced instrumental knowledge, which led to improvements of existing practices.

A very good example is the position of this epistemic community towards the introduction of Good Agricultural Practices (GAPs) and Sanitary and Phyto Sanitary (SPS) controls. The alignment of local rules to the EU's GAPs and SPS controls is considered essential for food exports. These controls were included in the first APs in order to allow greater access of Mediterranean products to the EU market (a key objective of the ENP).

Despite the controversial operation of the strict SPS controls for food producers and small farmers in developing countries (FAO, 2008), the knowledge of this network of experts did not challenge the added value of the SPS controls for rural areas. On the contrary, the work of the epistemic community helped the EU to become more efficient by introducing more specific benchmarks. It helped the EU to codify GAPs at the farm level and ENPARD to operate as a platform for training agricultural advisors and for encouraging small farmers and local cooperatives to apply the EU's standards (CIHEAM-IAMM, n.d.-c). In this sense, the epistemic community acted as a trainer, and expert knowledge was used by policymakers for improving the EU toolbox.

\section{Conclusion}

Drawing lessons from studies on epistemic communities, knowledge utility and policy learning, the article sheds some light on the role that knowledge generated by experts outside the EU institutions plays in the ENP. The article classified the contribution of epistemic communities in the discourse of two areas of the ENP: anti-corruption measures in the EaP and rural development of the AMCs.

As stated in the introduction, problems along the borders of the EU led policymakers to rethink existing strategies. Yet, contrary to studies which view EU foreign policy as an area where epistemic communities can shape decision-making, the findings of the article show that the expertexecutive nexus is not one-dimensional. Cognitive uncertainty led the European Commission to seek advice from experts, but the different foundations of uncertainty and scope factors had a differentiated impact on the use of knowledge (Table 1).

Table 1. Use of knowledge and impact on the two areas of the ENP

Ose of knowledge

In the first case study cognitive uncertainty originated from the absence of internal templates. The fact that the Panel shared the same normative and causal beliefs with powerful stakeholders did not turn this type of uncertainty into a condition that could lead to innovative solutions. Instead, the EU used knowledge for reinforcing already provided solutions for future action. Table 1 shows that the 
epistemic community complies with authority and adopts uncritically the working framework that was developed by GRECO. As a result, its contribution to the discourse is minimal and its most important function is to be put forward at appropriate times in order to promote the EU's actions to the EaP partners. At this point it must be mentioned that the existing findings are inconclusive regarding the aim of these actions and whether or not they are part of a wider (neoliberal) strategy of the EU for dominance in the region or an indicator of the absence of strategic vision. Further research is needed to address this question.

The conditions of the first case are not found in the operation of the epistemic community that was formed for helping the AMCs to develop their rural areas. Here, uncertainty was related to questions about the operation of previous initiatives due to the Arab revolts. In addition, the early access that experts had to policymakers allowed them to shape the direction of the new programme for the development of the Arab Mediterranean countryside. The epistemic community was successful in introducing a new working method that was based on the logic of integrated rural development.

However, this cognitive change does not mean that experts were successful in fundamentally altering every aspect of the EU's work in this sector. As in the first case, established practices, such as SPS and food controls, were not challenged. However, the objectives of the revised ENP offered policy space to experts for suggesting compatible improvements. These helped the EU to introduce its food controls to small farmers of the AMCs.

\section{Notes}

Council of Europe official, Phone interview 09 April 2019.

Eastern Partnership Network official, Phone interview 24 October 2019

Eurasia Partnership Foundation official, Phone interview 01 November 2019

European Commission official, Interview 14 October 2014, Brussels.

European Commission Official, Interview 14 October 2014, Brussels.

Lebanese state official, Interview 15 October 2014, Brussels.

\section{References}

Ademmer, E. (2015). Interdependence and EU-demanded policy change in a shared neighbourhood. Journal of European Public Policy, 22(5), 671-689.

Adler, E., \& Haas, P. M. (1992). Conclusion: Epistemic communities, world order, and the creation of a reflective research program. International Organization, 46(1), 367-390.

Bicchi, F. (2014). Information exchanges, diplomatic networks and the construction of European knowledge in European Union foreign policy. Cooperation and Conflict, 49(2), 239-259.

Bicchi, F., \& Bremberg, N. (2016). European diplomatic practices: Contemporary challenges and innovative approaches. European Security, 25(4), 391-406. 
Börzel, T., \& Hüllen, V. van. (2014). One voice, one message, but conflicting goals: Cohesiveness and consistency in the European Neighbourhood Policy. Journal of European Public Policy, 21(7), 1033-1049.

Börzel, T., \& Pamuk, Y. (2012). Pathologies of Europeanisation: Fighting Corruption in the Southern Caucasus. West European Politics, 35(1), 79-97.

Boswell, C. (2008). The political functions of expert knowledge: Knowledge and legitimation in European Union immigration policy. Journal of European Public Policy, 15(4), 471-488.

Bukovansky, M. (2006). The hollowness of anti-corruption discourse. Review of International Political Economy, 13(2), 181-209.

Casier, T. (2011). To Adopt or Not to Adopt: Explaining Selective Rule Transfer under the European Neighbourhood Policy. Journal of European Integration, 33(1), 37-53.

CIHEAM-IAMM. (n.d.-a). ENPARD PILOTE ACTION PROGRAMME IN TUNISIA. ENPARD South. Retrieved September 4, 2016, from http://www.enpard.iamm.fr/en/activities/programmesfor-technical-and-financial-support/110-pilote-action-programme-tunisia

CIHEAM-IAMM. (n.d.-b). ENPARD South. ENPARD South. Retrieved May 13, 2016, from http://enpard.iamm.fr/en/presentation/appoach-objectives

CIHEAM-IAMM. (n.d.-c). Morroco-The supporting programme to the national strategy on agricultural advisory services. CIHEAM-IAMM. Retrieved September 15, 2016, from http://www.enpard.iamm.fr/images/docs/EN/enpard_morocco_en.pdf

CIHEAM-IAMM. (2012a). Enjeux de l'économie politique agricole, alimentaire et rurale dans les pays arabes méditerranéens (Algérie, Egypte, Jordanie, Liban, Maroc et Tunisie) Document préparé par l'équipe CIHEAM-IAMM. CIHEAM-IAMM.

CIHEAM-IAMM. (2012b). Implementation of the ENPARD Programme by CIHEAM-IAMM Operator for DG DEVCO F2. CIHEAM-IAMM.

CIHEAM-IAMM. (2014). CIHEAM-IAM Montpellier. https://www.iamm.fr/content/search?SearchText=enpard 
Council of Europe. (2010). ENPI (Support to the Panel against Corruption)-Bridge Activities Project (August-November 2010) Summary. Corruption and Fraud Unit (CFU) /Economic Crime Division (ECD).

Council of Europe. (2017). Technical Papers and Expert Opinions. Action against Economic Crime and Corruption. https://www.coe.int/en/web/corruption/technical-papers

Council of Europe. (2018a). Eastern Partnership - Good Governance and the Fight against Corruption (EaP 1). Action against Economic Crime and Corruption.

https://www.coe.int/en/web/corruption/completed-projects/eap1-facility-corruption Council of Europe. (2018b). Reports EAP 1- Facility corruption. Action against Economic Crime and Corruption. https://www.coe.int/en/web/corruption/completed-projects/eap1-facilitycorruption/reports

Council of Europe. (2018c). Technical Papers EaP 1- Facility corruption. Action against Economic Crime and Corruption. https://www.coe.int/en/web/corruption/completed-projects/eap1facility-corruption/technical-papers

Cross, M. (2011). Security Integration in Europe: How Knowledge-based Networks Are Transforming the European Union. Ann Arbor: The University of Michigan Press.

Cross, M. (2013). Rethinking epistemic communities twenty years later. Review of International Studies, 39(1), 137-160.

Daviter, F. (2015). The political use of knowledge in the policy process. Policy Sciences, 48(4), 491505.

Delcour, L. (2016). The EU and Russia in Their "Contested Neighbourhood": Multiple External Influences, Policy Transfer and Domestic Change. London: Routledge.

Dery, D. (1986). Knowledge and Organizations. Review of Policy Research, 6(1), 14-25.

Dery, D. (1990). Data and Policy Change: The Fragility of Data in the Policy Context. New York: Springer.

Di Puppo, L. (2010). Anti-corruption interventions in Georgia. Global Crime, 11(2), 220-236. 
Di Puppo, L. (2014). The construction of success in anti-corruption activity in Georgia. East European Politics, 30(1), 105-122.

Dunlop, C. A. (2010). Epistemic communities and two goals of delegation: Hormone growth promoters in the European Union. Science and Public Policy, 37(3), 205-217.

Dunlop, C. A. (2014). The Possible Experts: How Epistemic Communities Negotiate Barriers to Knowledge Use in Ecosystems Services Policy. Environment and Planning C: Government and Policy, 32(2), 208-228.

Dunlop, C. A., \& Radaelli, C. M. (2013). Systematising Policy Learning: From Monolith to Dimensions. Political Studies, 61(3), 599-619.

EU Neighbourhood Info Centre. (2015, November 26). Agriculture and Rural Development: ENPARD to launch second phase in Morocco. Agriculture and Rural Development: ENPARD to Launch Second Phase in Morocco. http://www.enpiinfo.eu/medportal/news/latest/42894/Agriculture-and-Rural-Development:-ENPARD-tolaunch-second-phase-in-Morocco

European Commission. (2012, May 31). New Commission approach on agriculture in Neighbourhood launched. Development and Cooperation - EUROPEAID.

European Commission. (2014). Eastern Partnership Platform 1 "Democracy, Good governance and Stability"Core Objectives and Work Programme 2014-2017. European Commission.

European Court of Auditors. (2013). EU cooperation with Egypt in the field of governance (4/2013). European Court of Auditors.

Faleg, G. (2012). Between knowledge and power: Epistemic communities and the emergence of security sector reform in the EU security architecture. European Security, 21(2), 161-184. FAO. (2008). FAO : GAP : About Us. http://www.fao.org/prods/gap/

Gornitzka, A., \& Holst, C. (2015). The Expert-Executive Nexus in the EU: An Introduction. Politics and Governance, 3(1), 1-12. 
Haas, P. M. (1989). Do Regimes Matter? Epistemic Communities and Mediterranean Pollution Control. International Organization, 43(3), 377-403.

Haas, P. M. (1992). Introduction: Epistemic Communities and International Policy Coordination. International Organization, 46(1), 1-35.

Howorth, J. (2004). Discourse, Ideas, and Epistemic Communities in European Security and Defence Policy. West European Politics, 27(2), 211-234.

IEMed. (2016). European Neighbourhood Policy Review: European Union's Role in the Mediterranean (No. 6; Euromed Survey). IEMed.

Jones, A., \& Clark, J. (2008). Europeanisation and Discourse Building: The European Commission, European Narratives and European Neighbourhood Policy. Geopolitics, 13(3), 545-571.

Jones, B., Thomas, H., \& Wolfe, M. (2014). Policy Bubbles. Policy Studies Journal, 42(1), 146-171.

Keck, M., \& Sikkink, K. (1999). Transnational advocacy networks in international and regional politics. International Social Science Journal, 51(159), 89-101.

Kelley, J. (2006). New Wine in Old Wineskins: Promoting Political Reforms through the New European Neighbourhood Policy*. JCMS: Journal of Common Market Studies, 44(1), 29-55. Kourtelis, C. (2018). From Neglect to Selective Engagement: The EU Approach to Rural Development in the Arab Mediterranean after the Arab Uprisings. Mediterranean Politics, 23(1), 23-42.

Kupatadze, A. (2012). Explaining Georgia's anti-corruption drive. European Security, 21(1), 16-36. Lippert, B. (2006). Beefing up the ENP: Towards a Modernisation and stability partnership. The International Spectator, 41(4), 85-100.

Memorandum of Understanding between the Council of Europe and the European Union. (2007). Delegation of the European Union to the Council of Europe. https://eeas.europa.eu/delegations/council-europe/6983/memorandum-understandingbetween-council-europe-and-european-union_en

Mesnil, B. (2012). The hesitant emergence of maximum sustainable yield (MSY) in fisheries policies in Europe. Marine Policy, 36(2), 473-480. 
Milcher, S., \& Slay, B. (2005, April 8). The economics of the 'European Neighbourhood Policy': An initial assessment. Europe After the Enlargement, Warsaw.

Narro, P., \& Moreno, J. (2014). Opinion of the European Economic and Social Committee on 'EUMorocco Trade Relations' (own-initiative opinion) (2014/C 214/03). European Economic and Social Committee. http://eur-lex.europa.eu/legalcontent/EN/TXT/?uri=CELEX\%3A52013IE3614

Nasuti, P. (2016). Administrative Cohesion and Anti-Corruption Reforms in Georgia and Ukraine. Europe-Asia Studies, 68(5), 847-867.

Radaelli, C. M. (1999). The public policy of the European Union: Whither politics of expertise? Journal of European Public Policy, 6(5), 757-774.

Rathbun, B. C. (2007). Uncertain about Uncertainty: Understanding the Multiple Meanings of a Crucial Concept in International Relations Theory. International Studies Quarterly, 51(3), $533-557$.

Ray, C. (2000). The EU leader Programme: Rural Development Laboratory. Sociologia Ruralis, 40(2), $163-171$.

Rinaldi, N. (2012). On Trade for Change: The EU Trade and Investment Strategy for the Southern Mediterranean following the Arab Spring revolutions (2011/2113(INI)).

Roccu, R., \& Voltolini, B. (2018). Framing and reframing the EU's engagement with the Mediterranean: Examining the security-stability nexus before and after the Arab uprisings. Mediterranean Politics, 23(1), 1-22.

Sampson, S. (2008). Corruption and Anti-Corruption in Southeast Europe: Landscapes and Sites. In L. De Sousa, P. Marmour, \& B. Hindess (Eds.), Governments, NGOs and Anti-Corruption: The new integrity warriors. Abingdon: Routledge.

Schatzki, T. R. (2012). A primer on practices. In J. Higgs (Ed.), Practice-based education. Rotterdam: Sense Publishers. 
Schueth, S. (2011). Assembling International Competitiveness: The Republic of Georgia, USAID, and the Doing Business Project. Economic Geography, 87(1), 51-77.

Sharman, A., \& Holmes, J. (2010). Evidence-based policy or policy-based evidence gathering?

Biofuels, the EU and the 10\% target. Environmental Policy and Governance, 20(5), 309-321.

Teti, A. (2012). The EU's First Response to the 'Arab Spring': A Critical Discourse Analysis of the Partnership for Democracy and Shared Prosperity. Mediterranean Politics, 17(3), 266-284.

Tisne, M., \& Smilov, D. (2004). From the Ground Up: Assessing the Record of Anticorruption Assistance in Southeastern Europe (Policy Studies Series). Central European University.

Van Ballaert, B. (2015). The Politics behind the Consultation of Expert Groups: An Instrument to Reduce Uncertainty or to Offset Salience? Politics and Governance, 3(1), 139-150.

Verdun, A. (1999). The role of the Delors Committee in the creation of EMU: An epistemic community? Journal of European Public Policy, 6(2), 308-328.

Voltolini, B. (2016). Lobbying in EU Foreign Policy-making: The Case of the Israeli-Palestinian Conflict. Abingdon: Routledge.

Weiss, C. H., Murphy-Graham, E., \& Birkeland, S. (2005). An Alternate Route to Policy Influence: How Evaluations Affect D.A.R.E. American Journal of Evaluation, 26(1), 12-30.

Wichmann, N. (2010). Rule of Law Promotion in the European Neighborhood Policy: Normative or Strategic Power Europe?, Baden-Baden: Nomos.

Zito, A. R. (2001a). Epistemic communities, collective entrepreneurship and European integration. Journal of European Public Policy, 8(4), 585-603.

Zito, A. R. (2001b). Epistemic communities, European Union governance and the public voice. Science and Public Policy, 28(6), 465-476. 